\title{
血管柄付遊離腸骨移植による下䫑機能再建例の術後機能回復について
}

\author{
佐藤淳一・瀬戸晥一・松浦 正朗 \\ 川口浩司・濱田良樹·金村弘成 \\ 森田雅之·林和喜·中尾 泉* \\ 金井郁代**·佐々木眞一
}

\section{Oral functional recovery after mandibular reconstruction using vascularized iliac crest}

\author{
Jun-ichi SAto $\cdot$ Kan-ichi Seto $\cdot$ Masaro Matsuura \\ Koji Kawaguchi $\cdot$ Yoshiki Hamada $\cdot$ Hironari Kanemura \\ Masayuki Morita - Kazuki Hayashi - Izumi NaKaO* \\ Ikuyo KANAI** Shin-ichi SASAKI
}

\begin{abstract}
We have previously reported that the ilium was best suited for reconstruction of the mandible because of its shape and volume, including both thickness and height. Here we report the results of clinical studies of 38 patients in whom vascularized iliac crest (VIC) was used to reconstruct the mandible.

The procedure used for resection of the mandible was unilateral segmentectomy in 23 patients, bilateral segmentectomy in 11 patients, and hemimandibulectomy in 3 . The mandible underwent primary reconstruction in 30 of the 38 patients. For the skin flap, a forearm flap was used in 18 of the patients. The complications included gait disturbances in 32 of the 38 patients $(81 \%)$ within 3 months after the operation, but this disturbance resolved within 1 year. Dysesthesisa of the femoral region was experienced by 18 of the 38 patients and disapperared within 1 year after the operation in most cases. The VIC had to be removed in 4 of the 38 patients (10\%). Dentures were worn by 32 patients ( $85 \%)$ from 3 to 6 months after mandibular reconstruction. The reasons for removal of the graft were necrosis of the groin flap and VIC in one patient, and thrombosis in two patients. The absorption rate of the grafted bone was measured by orthopantomography. At of 3 years after the operation, the average bone resorption rate was about $5 \%$ in 34 patients.

Ten patients of 38 patients received implant-anchored prostheses, and 41 Brånemark Mark II and 7 ITI Bonefit implants were inserted via an intraoral approach. After treatment with the implant-anchored prosthesis, masticatory function was better than while wearing conventional dentures, but speech function was not improved.
\end{abstract}

鶴見大学歯学部口腔外科学第一講座

(主任 : 瀬戸晥一教授)

*府中恵仁会総合病院歯科口腔外科

(主任 : 中尾 泉部長)

**東芝林間病院歯科口腔外科

(主任 : 金井郁代部長)

First Department of Oral \& Maxillofacial Surgery, School of Dental Medicine, Tsurumi
University (Chief: Prof. Kan-ichi Seto)

* Department of Dentistry and Oral Surgery, Fuchu Keijinkai General Hospital (Chief: Izumi Nakao)

**Department of Dentistry and Oral and Maxillofacial Surgery, Toshiba Rinkan Hospital (Chief: Ikuyo Kanai)

受付日：平成 8 年 9 月 20 日 
We conclude that the use of a VIC in a one-stage operation for reconstruction of the mandible allows the patient to wear dentures early after the operation and facilitates the recovery of mastication and facial appearance, with no serious complications. Bone volume was sufficient, and the success rate of the bone grafts was high. Masticatory function was improved by having the patient wear an implantanchored prosthesis.

Key words: vascularized iliac crest（血管柄付遊離腸骨）, mandibular reconstruction (下顎の再建), oral functional reconstruction (ロ腔機能再建), dental implant (インプラント)

緒

口腔悪性腫瘍外科療法の成否は, 再建手術に掛かっ ているといっても過言ではない1，2). しかし口腔機能 は微妙で多様かつ複雑であるため, 未だに十分な術後 口腔機能の回復が行われているとは言い難いのが現実 である. 特に下顎骨は顔貌や咀嚼機能回復を行う上で 重要な要素であり, その再建は最も難しいと言われて いる。一般には骨組織を伴う広範な欠損の場合は，皮 弁を用いて量的再建に終始している場合が多い。しか し著者らはこのような場合, 口腔癌の根治性と術後機 能を考慮し, 口腔機能再建, つまり下顎骨欠損への移 植骨による正確な再建を行っており, 残存歯牙の機能 を妨げる事なく，再建下顎骨上においても義歯あるい はインプラント義歯を使用し, 口腔機能を営めるよう にすることが肝要であると考えている.そこで著者ら は次のような原則にしたがって下顎骨再建を行ってい る.すなわち, 1 . 移植骨は下顎骨の形態や骨量に類 似した腸骨で行う，2，移植骨の被覆皮弁は薄く嵩張 らない前腕皮弁で行う， 3 . 骨移植は可能な限り一期 的に行う，4.下顎骨に対してプレートのみをスペー スリテイナーとして用いることは再建と言わず，自家 骨移植を再建の基本とする。このような原則に沿って 骨移植を行う場合，血管柄を付けない遊離腸骨（以後 NVIC と呼称）移植は小臼歯から下顎角部までの欠損 の二次再建例に使用し, 血管柄付遊離腸骨 (以後 VIC と呼称）は一次再建，オトガイ部を含む再建，延長骨 移植, 放射線治療後の再建に適用している。.また血管 柄付き遊離骨の供給側に関しては, 肋骨, 腓骨, 肩甲 骨, 腸骨が使用されているが, これらの骨を比較検討 した結果では, 血管柄の長さではあまり大差がなく, 骨の厚さや高さが下顎骨と同等量採取可能なのは腸骨 のみであることを，すでに報告した ${ }^{3)}$. しかし VIC 移 植の多数例を対象した報告はきわめて少なく David らの35例 ${ }^{4)}$, Riediger らの36例 ${ }^{5)}$ の報告があるに過 ぎず, 我国においては著者らの18例 ${ }^{1)}$ の報告があるに 過ぎない.しかもこれらは移植術式とその結果につい て論じたもので, 術後機能回復のための手術術式を論 じたものはない. そこで今回, VIC について術後機能 回復のための再建方法とその結果について検討した.

\section{対象と方 法}

対象は, 1987年11月から 1996年12月までに当科およ び関連施設で行った下顎切除後の VIC 移植 38 例とし た.これらの症例の病理組織型別では, 扁平上皮癌 26 例 (68\%) で,ついでエナメル上皮腫の 9 例, 放射線骨 髄炎 3 例, 骨肉腫と混合腫崵各 1 例であった。切除様 式では片側区域切除23例（71\%）で，願部を含めて両 側にわたる区域切除11例，下顎頭を含む片側離断 3 例 であった（表 1 ）。また再建時期では一次再建 30 例 $(80 \%)$, 二次再建 8 例 $(20 \%)$ と一次再建例が多数を 占めていた。併用皮弁症例はVIC 症例 38 例中 24 例 (63\%) で，これらのうち前腕皮弁が18例 (75\%) で最 も多く，ついで PMMC の 2 例，前腕皮弁と PMMC を併用したもの 2 例, 前腕皮弁と単径皮弁を併用した もの, 単径皮弁を併用したもの各 1 例であった.

$$
\text { 結果 }
$$

合併症では歩行障害は術後 3 か月目で31例 (81\%) に認められ， 3 例は術後 1 年以降も歩行障害が残った が, 術後 3 年, 4 年, 5 年で歩行障害は消失していた。 また大腿部の知覚麻痺は術後 3 か月目で18症例に認め られ，1例を除き全例で回復していた。この 1 例は術 後 6 年目であるが, 知覚鈍麻がいまだに残っていた (表 2 ).

生着状況は即時再建は30例中 28 例 $(93 \%)$, 二次再建 は 8 例中 6 例生着し, 全体の生着率は38例中 34 例 (90\%) であった。これらの症例の移植骨除去理由は単 径皮弁が壊死したため腸骨も除去したもの 1 例，VIC が移植後 6 か月目に感染したもの 1 例, 深腸骨回旋動

表 1 下顎の切除様式別症例

\begin{tabular}{lc}
\hline 片側に限局した区域切除 & $23(2)$ \\
両側にわたる区域切除 & $11(8)$ \\
下顎頭を含む片側離断 & 4 \\
\hline & $38(10)$ 症例 \\
\hline & ( ) : インプラント症例
\end{tabular}


表 2 合併症

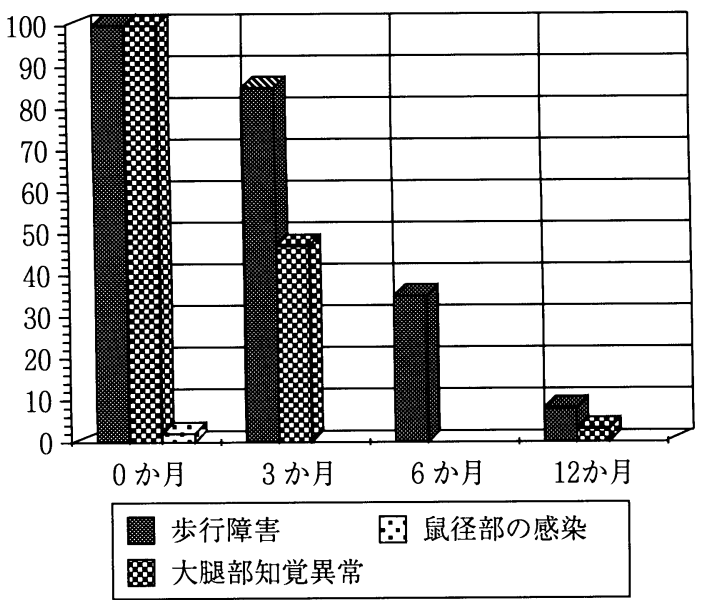

表 3 移植骨骨量の変化

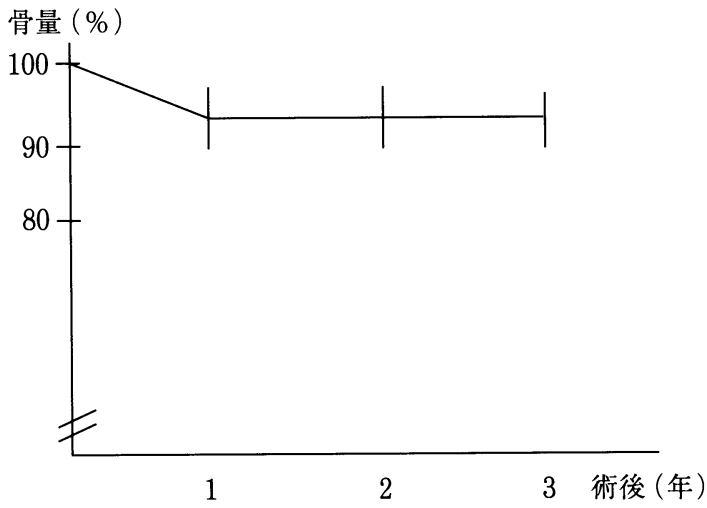

静脈の血栓のため除去したもの各 1 例であった. 悪性 腫瘍切除後一次再建で前腕皮弁と血管柄付腸骨移植を 同時併用した 10 症例の手術時間は最長 22 時間最短 10 時 間で, 平均15.8時間であった. 義歯の装用状況では術 後 $3 \sim 6$ か月間に装用可能であったものは，32/38 （84\%）の装用率であった. 非装用の理由としては, 経 過観察中, 腸骨を除去したため, 腫瘍が再発したため などであった。

移植骨の吸収量は, パノラマ X 線写真上で移植骨の 断端 2 か所と中央部 1 か所の合計 3 か所で移植骨の高 さを測定し, 移植時を $100 \%$ とし，3 か所の平均值とし て算出した.この結果では術後 1 年経過後はほとんど 吸収は認められず, 一年後の平均吸収率は $5 \%$ であっ た(表 3 ).

固定したプレートは $\mathrm{AO}$ の再建用プレート 27 例, Titanium Hollow Screw Reconstruction Plate System (THORP) 9 例, ミニプレート2例であった. インプラントを植立したものは10症例で，これらは
表 4 使用インプラント

\begin{tabular}{|c|c|c|c|c|c|}
\hline \multicolumn{2}{|c|}{$\begin{array}{l}\text { ブローネマルク } \\
\text { スタンダード }\end{array}$} & \multicolumn{2}{|c|}{$\begin{array}{l}\text { ITI ボーン } \\
\text { フィット }\end{array}$} & \multicolumn{2}{|c|}{$\begin{array}{l}\text { ブローネマルク } \\
\text { マーク II }\end{array}$} \\
\hline $20 \mathrm{~mm}$ & 6 本 & $16 \mathrm{~mm}$ & 5 本 & $18 \mathrm{~mm}$ & 27本 \\
\hline \multirow[t]{2}{*}{$18 \mathrm{~mm}$} & 2 本 & $14 \mathrm{~mm}$ & 2 本 & $16 \mathrm{~mm}$ & 6本 \\
\hline & 8 本 & & 7 本 & & 33本 \\
\hline
\end{tabular}

表 5 咀嚼能力 (山本の咬度表による)

\begin{tabular}{r|cc}
\hline & 義歯装用時 & $\begin{array}{c}\text { インプラント } \\
\text { による補綴後 }\end{array}$ \\
\hline 1 & 4 & 5 \\
2 & 5 & 5 \\
3 & 4 & 4 \\
4 & 5 & 5 \\
5 & 3 & 4 \\
6 & 3 & 4 \\
7 & 3 & 4 \\
8 & 4 & 5 \\
9 & 4 & 5 \\
10 & 5 & 5 \\
\hline
\end{tabular}

両側にわたる区域切除 6 例, 片側区域切除 4 例で, 併 用皮弁では前腕皮弁 6 例, PMMC 1 例であった. イン プラントの植立本数は 48 本で, これらの内訳はブロー ネマルクマーク IIインプラント 33 本, ブローネマルク スタンダードインプラント 8 本, ITI 充実スクリュー7 本であった (表 4 ). これらのうち, 二次手術前後の比 較的早期にオッセオインテグレイションの消失があり 除去したものは 1 症例で, ブローネマルクマーク II イ ンプラント 1 本であった. またこれらの上部構造は術 者可撤式補綴物 8 例, オーバーデンチャー 2 例であっ た.これらのインプラント補緅を行った後と, 義顎を 装用時で口腔機能を比較検討すると, 山本の硬度表 6) による咀嚼能率の聞き取り評価法ではインプラント義 歯を装着後に改善傾向がみられた. また食べ物の状態で は食べ物の形状や性状を変えないでそのままの状態で 摂取可能症例が増える傾向にあった（表 5 ). 会話明暸 度 ${ }^{7)}$ ではほとんど改善傾向がみられなかった（表 6 ).

以下に代表症例 2 例を示す.

症例

症例 1 は32歳男性で口底癌 $\mathrm{T}_{4} \mathrm{~N}_{2 \mathrm{~b}}$ （写真 1 ）で, 舌 可動部全摘, 口底切除, 願部を含めて下顎骨両側にわ たる区域切除, 右全頸部郭清, 左上頸部郭清, A-O プ レートによる下顎骨の仮り止め固定（写真 2 ）を行っ 
表 6 会話明瞭度

\begin{tabular}{r|cc}
\hline & 義歯装用時 & $\begin{array}{c}\text { インプラント } \\
\text { による補緅後 }\end{array}$ \\
\hline 1 & 2 & 2 \\
2 & 1 & 1 \\
3 & 2 & 1 \\
4 & 1 & 1 \\
5 & 3 & 3 \\
6 & 2 & 2 \\
7 & 3 & 2 \\
8 & 2 & 2 \\
9 & 2 & 2 \\
10 & 1 & 1 \\
\hline
\end{tabular}

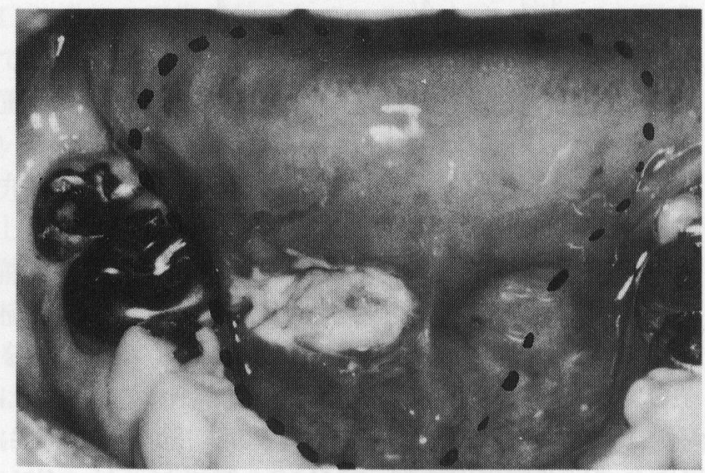

写真 1 初診時口腔内写真

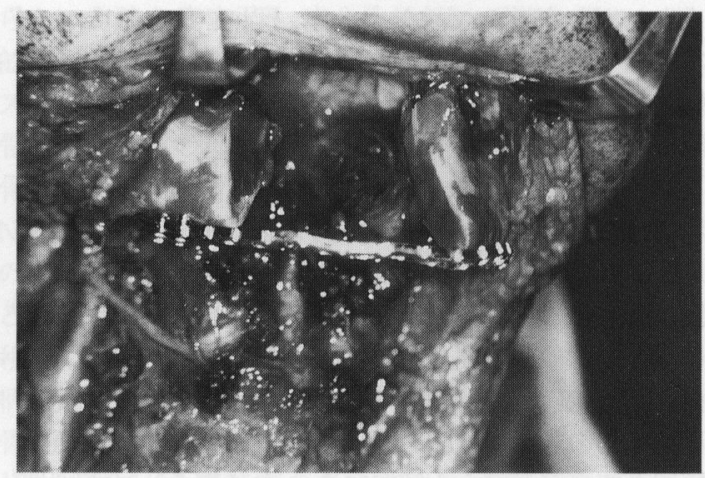

写真 2 術中写真. 舌可動部全摘, 口底切除, 両側に わたる下顎区域切除, 右側全頸部郭清, 左側上頸 部郭清を行った.

た. 即時再建を行うため, 前腕皮弁と血管柄付腸骨挙 上後 (写真 3,4$)$ ，まず口腔内軟組織欠損を前腕皮弁 にて再建 (写真 5 ) し，つぎにVIC に割をいれオトガ イ部を形成し，A-Oの再建用プレートにて固定し，下 枵骨下縁に固定した仮り止め固定用のプレートは除去

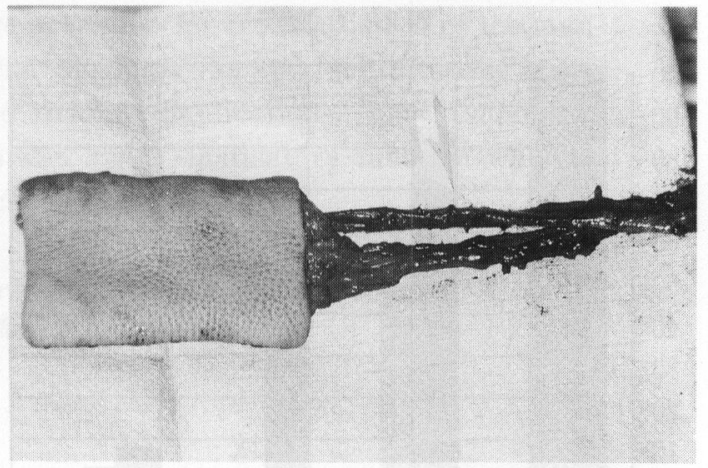

写真 3 前腕皮弁挙上時

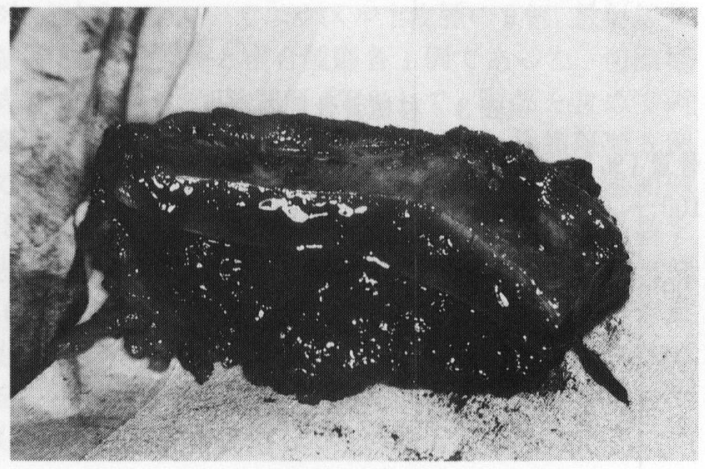

写真 4 VIC 挙上時

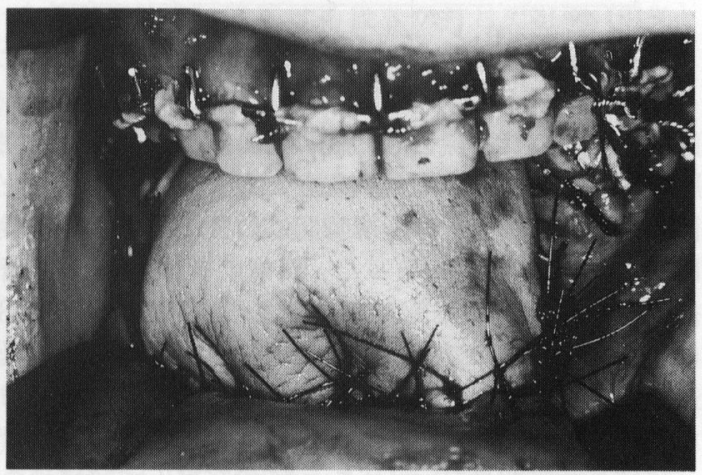

写真 5 口腔内軟組織欠損を前腕皮弁にて再建

した (写真 6 ). 術後 3 か月目の口腔内所見 (写真 7 ) とオルソパントモ像 (写真 8 ) で, 口蓋音を再現する ため腸骨, 内腸骨筋, 前腕皮弁で口蓋側に量的再建を 行った. 顔貌の変型も術前（写真 $9 \mathrm{a}$ ) と術後（写真 9 b) を比較しあまり認められなかった. 術後 5 か月目 


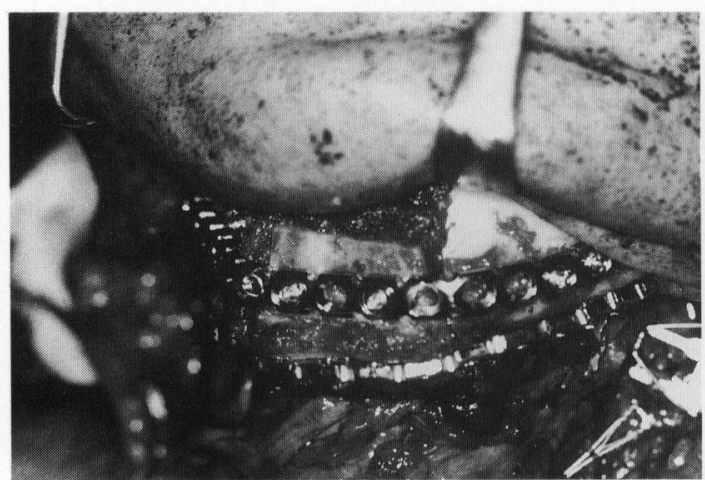

写真 6 VIC に割を入れてオトガイ部を形成し， A-O の再建用プレートにて固定.

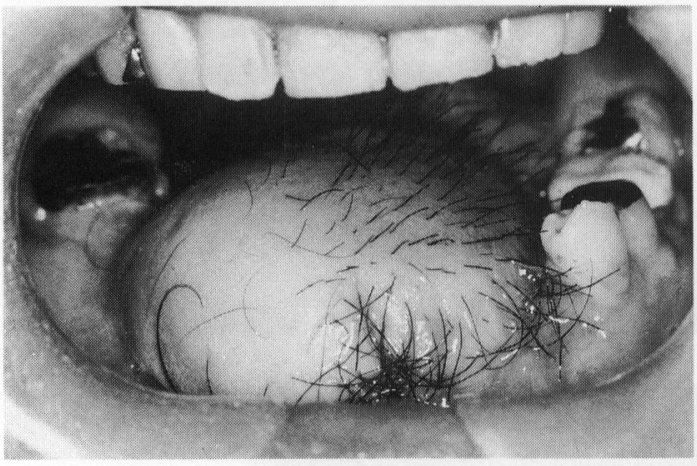

写真 7 術後 3 か月目の口腔内写真

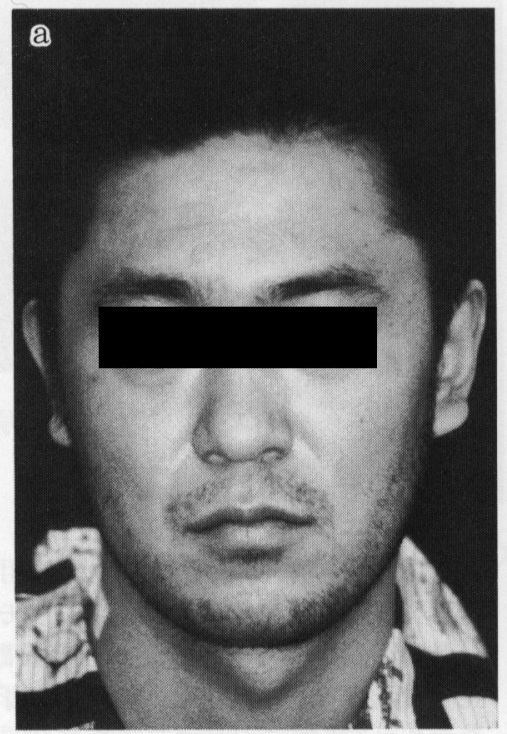

に義歯装着時 (写真10) のもので,この時術後口腔機 能評価では, 会話明瞭度では 2 ,すなわち「ときどき 判らない: 言葉がある」であった. 咀嚼機能では山本 の硬度表 5 でたくわん以外は捸取可能であった。術後 1 年 5 か月目でプレート除去を行ったが, VIC のオト ガイ部で割を入れた部位や下顎骨の切除断端部と VICの接合は良く生着していた（写真11).このとき 同時にブローネマルク・スタンダードインプラントを 5 本植立し (写真12), インプラント植立後 6 か月目で 二次手術を行い, 術者可撤式のインプラント義歯を装 着した (写真 13,14$)$. 会話明瞭度ではあまり改善傾向 は認められなかったが, 以前の義歯に比較しインプラ ント義歯は小型化し維持が強固であるため, 会話しや すくなったと述べていた. また咀嚼機能ではたくわん も摂取可能となっており, 山本の硬度表でも 6 まであ がり,さらにほとんどの食品をそのままの状態で捸取

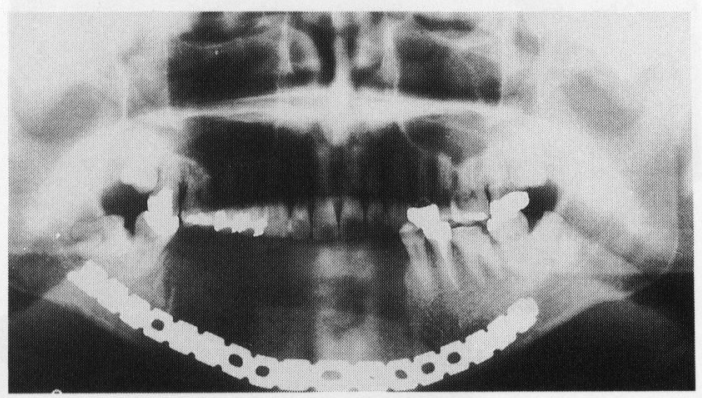

写真 8 術後 3 か月目のオルソパントモ像

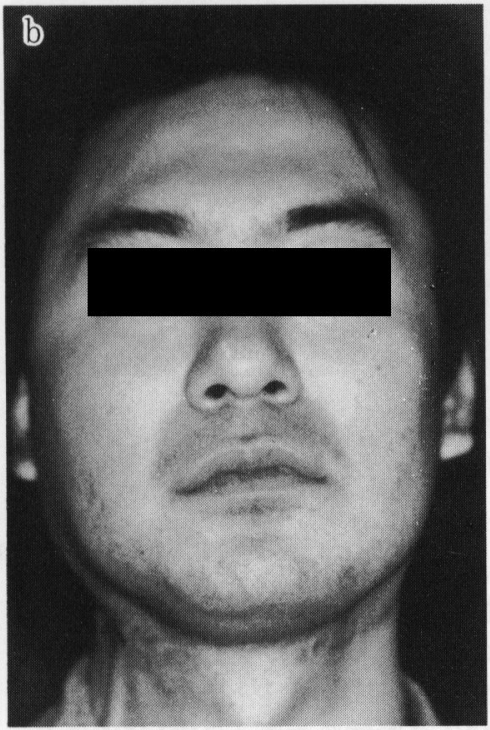

马真 $9 \mathrm{a}$ : 術前の顔貌, $\mathrm{b}$ : 術後の顔貌 


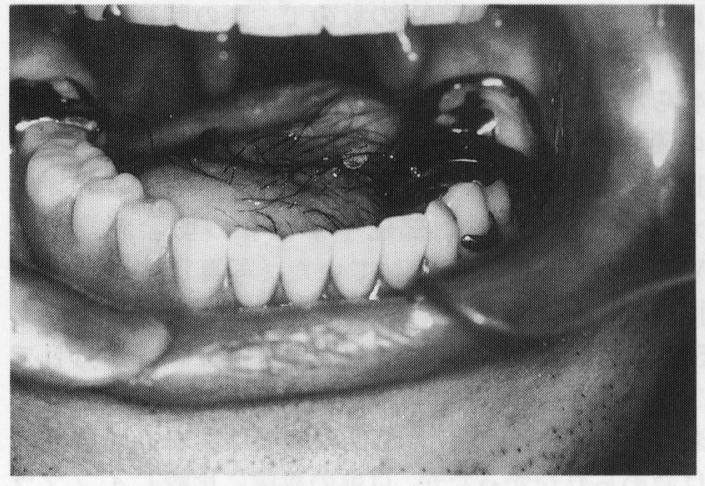

写真10 義歯装着時の口腔内写真

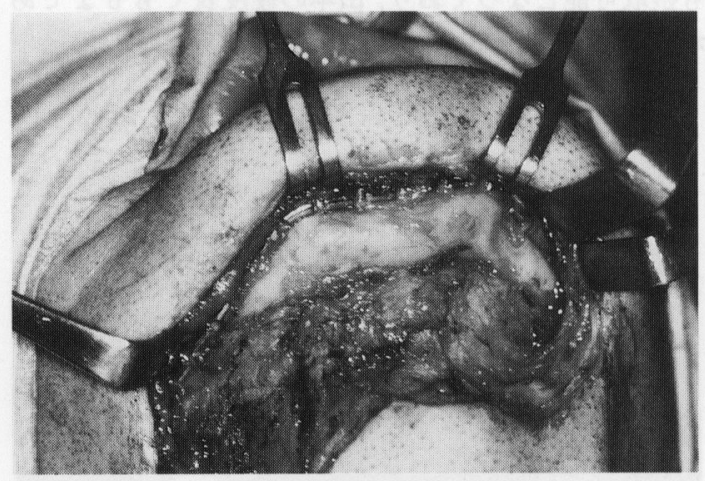

写真11 術後 1 年 5 か月目のプレート除去手術時

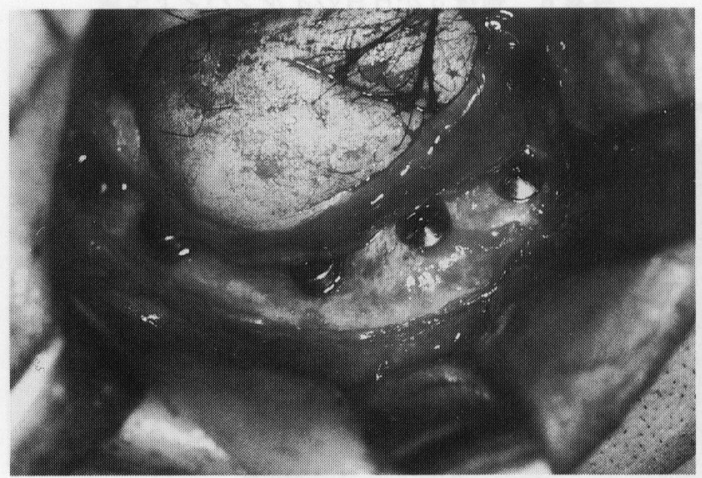

写真12 ブローネマルク・スタンダード・インプラ ントを 5 本植立.

可能となっていた.

症例 2 は64歳男性で右下顎歯肉扁平上皮癌 T $3 \mathrm{~N} 1$ であった (写真15)。 そこで下顎骨の半側切除, 右の全 頸部郭清, PMMCによる即時再建を行った（写真16). 術後約 1 年で PMMC の脂肪除去術と VIC による延 長骨移植による二次再建を行った (写真17). このとき

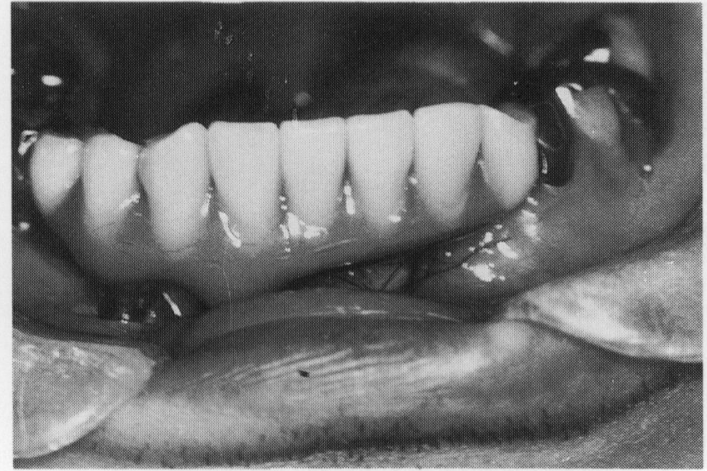

写真13 術者可徹式のインプラント義歯装着時

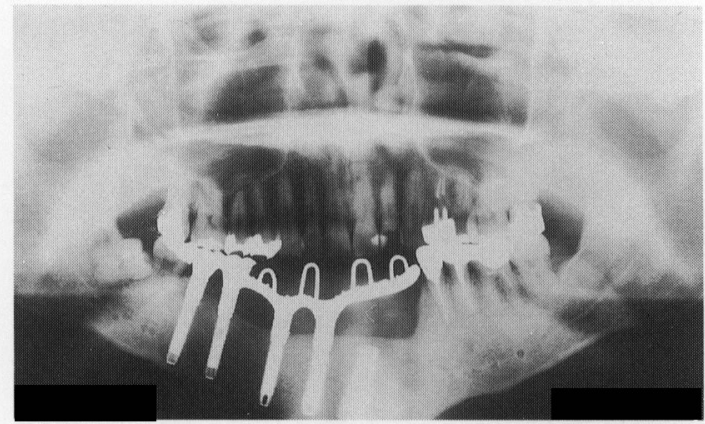

写真14 インプラント義歯装着後のオルソパントモ像

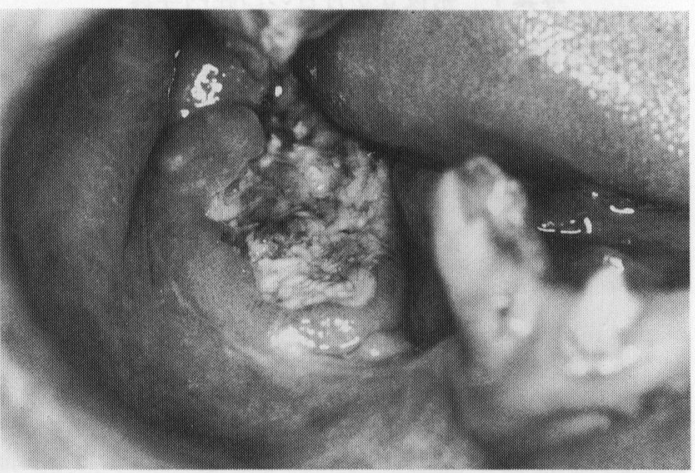

写真15 初診時口腔内写真

移植骨は残存下顎骨にA-O の再建用プレートにて固 定し, 術後約 3 か月のオルソパントモ像では十分な移 植骨の骨量と下顎骨への生着状態が観察された（写真 18). 術後 7 年経過しているが移植骨量に変化は認め られない. 術後 6 か月で義歯を製作したが, 義歯の維 持, 安定が得られず装用不能であった. 顔貌では術前 


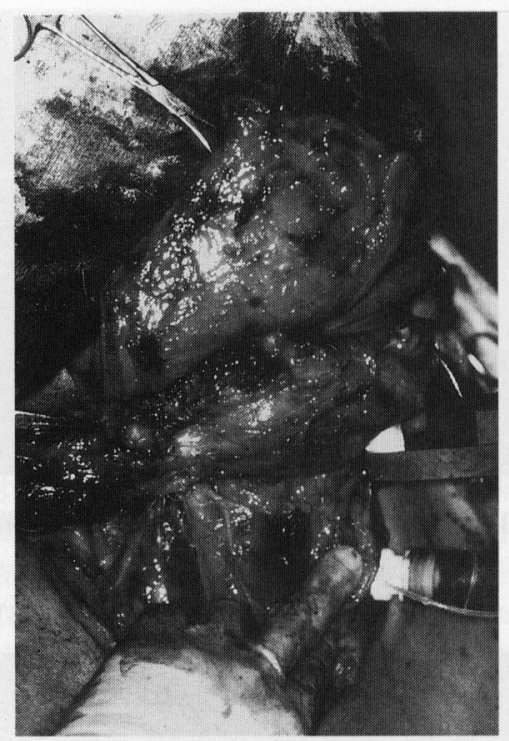

写真16 下顎半側切除および右側全頸部郭清を行っ たところ.

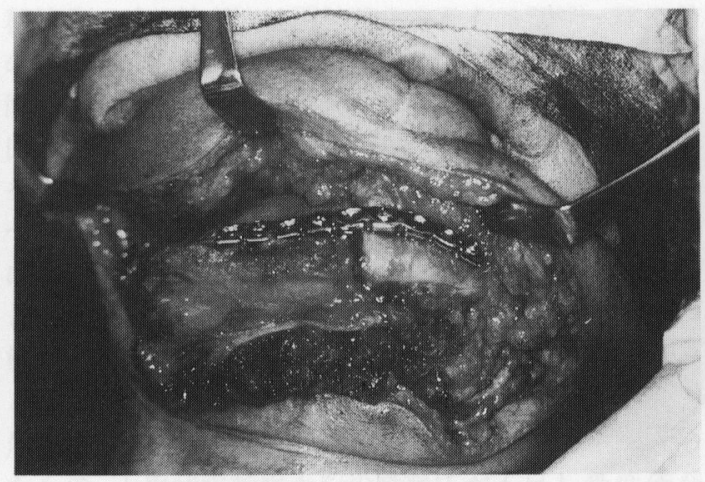

写真17 VIC による二次再建を行った

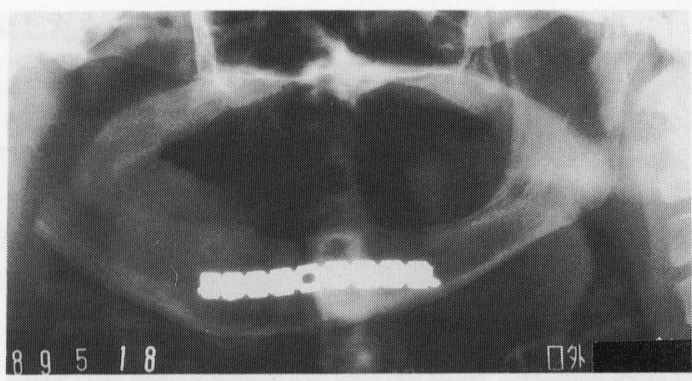

写真18 術後 3 か月目のオルソパントモ像

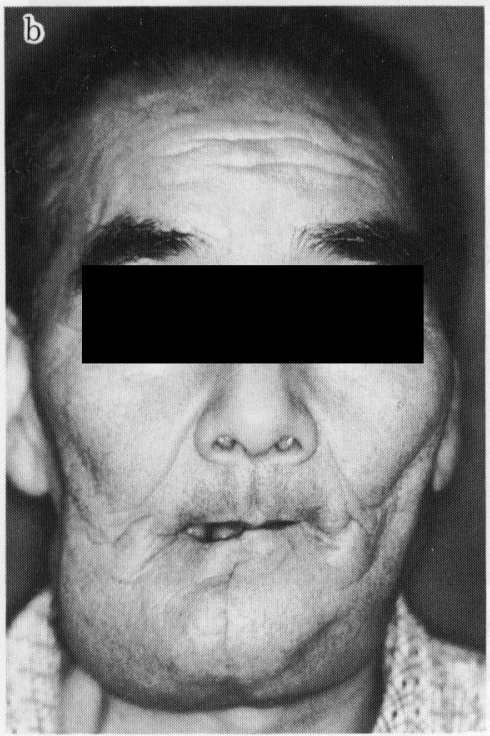

写真19 a : 術前の顔貌, $\mathrm{b}$ : 術後の顔貌

術後と比較し, 左右に多少の非対象が認められるがほ ぼ満足が得られた (写真19). 移植後約 1 年でプレート 除去を行い (写真 20$)$, 同時に下顎の囲繞結紮と皮膚移 植による顎堤形成術と, 残存下顎骨への ITI 中空スク
リューインプラントの植立を行った（写真21, 22) (本 症例は残存下顎骨にインプラントを植立したものであ り, VIC に植立したインプラントの症例には含めてい ない). インプラント植立後 4 か月でアンカーヘッド 


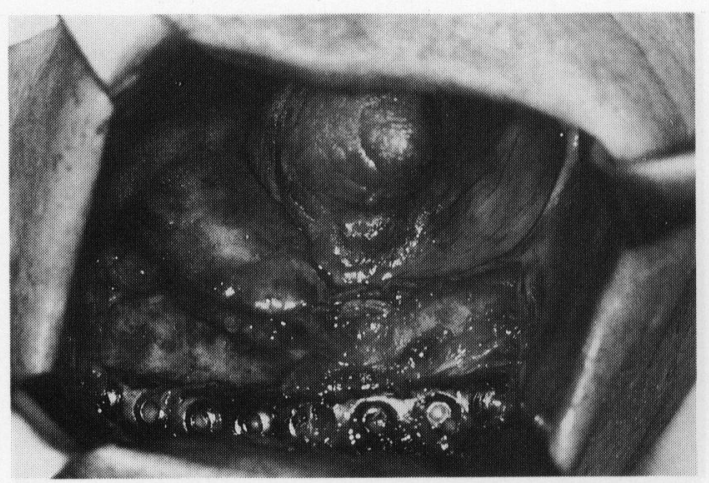

写真20 プレート除去時の口腔内写真

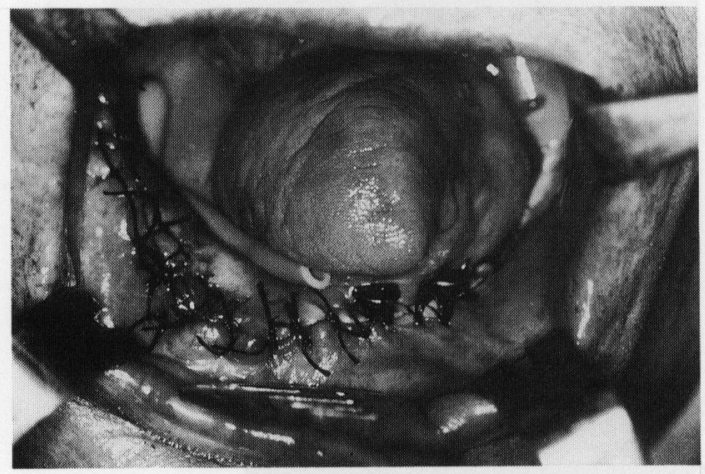

写真21 残存下顎骨への ITI 中空スクリューインプ ラントの植立と顎堤形成術を行った.

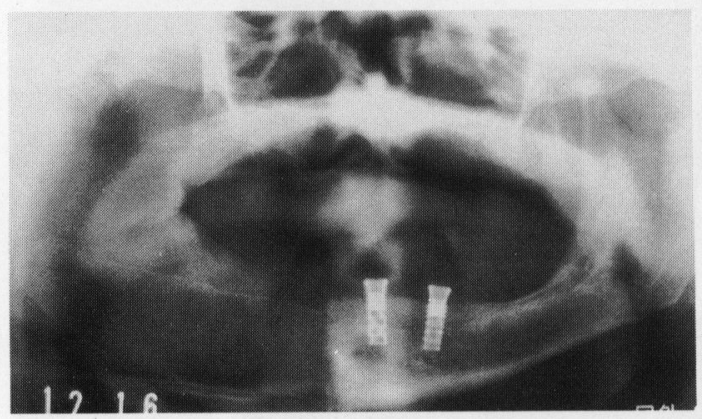

写真22 ITI 中空シリンダー型インプラントを残存 下顎骨に植立した後のオルソパントモ像

をインプラントに装着し(写真23), オーバーデンチャー とした (写真24). インプラント義歯にすることで, 義 歯床は小さく，装用感に優れ，咬合の安定が得られ， 柔らかいものや小さくした食べ物であれば摂取可能で あった。

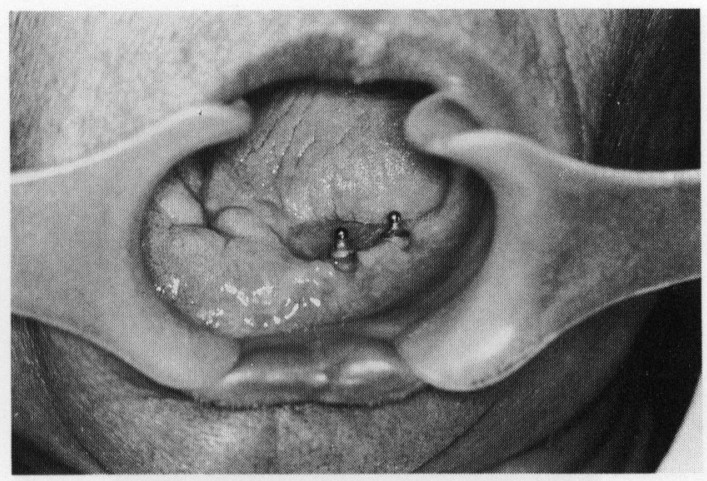

写真23 インプラントにアンカーヘッドを装着した ところ

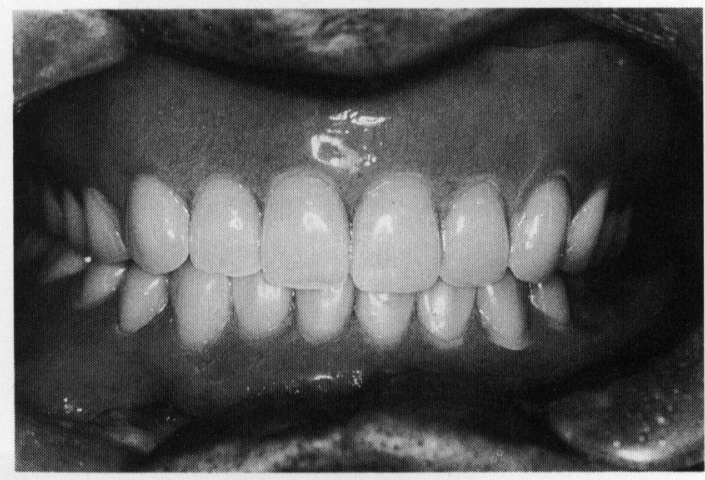

写真24 オーバーデンチャー装着時

考察

血管柄を付けない遊離骨移植と血管柄付遊離骨 移植の下顎骨の再建の適応について

下顎骨の再建材料として臨床応用が行われているも のは, 血管柄付遊離骨移植 $4,8 \sim 16)$, 血管柄を付けない 遊離骨移植 ${ }^{17,18)}$, 骨筋皮弁 ${ }^{19 \text {-24) }}$, 切除下顎骨を凍結 ${ }^{25)}$ あるいは煮沸26)して移植する方法, ダクロンポリウレ タン27) などの網トレーに海面骨などを包み移植する 方法, ヒドロキシアパタイトブロック 28 30）を利用す る方法などである.この下顎骨の再建材料としての条 件にあったものを上記の臨床応用可能な再建材料より 選択すると, living bone を選択せざるを得ない,つま り血管柄付遊離骨移植と有茎骨移植が適していると思 われる.しかし有茎骨移植は移動できる範囲や, 採取 可能な骨も鎖骨 ${ }^{19,20)}$, 肋骨 ${ }^{21}$ 23), 胸骨 ${ }^{24)}$, などに限ら れており，血管柄付遊離骨移植が最終的な選択になる と思われる.オトガイ部を含む再建では，骨に割を入 れ湾曲することが可能で, 感染に対しても強い血管柄 付の骨移植が再建時期にかかわらず適応と思われる. 
また延長骨移植を行う場合には, 血管柄を付けない遊 離骨移植では吸収が著明であり 31 33)，吸収がほとん どない血管柄付骨移植の適応と思われる。

\section{移植骨の選択について}

下顎骨への血管柄付骨移植には腸骨 4,8，9)，肋

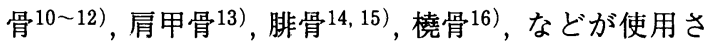
れた報告があるが, 最近主に臨床で使用されているの は, 腸骨, 肩甲骨, 腓骨であり,これらの栄養血管の走 行と分布ならびに骨の高さ, 厚み, 採取可能な長さに ついて計測を同一個体間で, 系統的に比較した結果で は, 下顎骨の高さを再現可能な移植骨は腸骨のみであつ たと北村 ${ }^{3)}$ が述べている.しかし臨床的には腓骨を 2 つ折りにし，歯槽骨の高さを回復する試みも行われ， 良好な結果が得られたとする報告もある15). 移植骨と して採取可能な長さは20～ $26 \mathrm{~cm}$ と言われているが, 十分な下顎骨の高さを再現するため 2 つ折りにすると 実際に使用可能な長さは10 $13 \mathrm{~cm}$ で腸骨の採取可能 の長さ10〜 $14 \mathrm{~cm}$ とあまり違いはない. 一方腸骨の場 合, 断面が下顎骨の断面に比較的類似し, 腸骨の外形 も下顎骨の湾曲に近いという形態的特徴を活用できる. すなわち下顎骨の再建の第一選択としては, VIC を用 いた一次再建が, 咀嚼機能や顔貌の回復のために最も 適していると思われる。

\section{併用皮弁について}

VIC と一緒に挙上可能な皮弁としては, 単径皮弁で あるが,すでに報告があるように皮弁が高張り，自由 度がなく, 皮弁血行が不安定で, 顔面皮虐との色調が 不調和 ${ }^{8)}$ であるため, 著者らも口腔粘膜欠損や顔面の 皮膚欠損の再建にはあまり使用していない. David ら 4 ) も述べているように, 著者らも移植骨の被覆皮弁とし ては, 口腔内は薄く可動性に富んでいる前腕皮弁がよ いと考えている. その理由としては術後 $3 \sim 4$ か月の 間に義歯を装着し早期に咀嚼機能の回復を行うために は, 前腕皮弁のように薄く嵩張らない皮弁でなければ 義歯床下粘膜として機能させることは困難であるため である。

\section{移植骨の吸収について}

NVIC では架橋骨移植における骨の吸収量は $15 \%$ か ら40\% ${ }^{34 \sim 36)}$ で, 延長骨移植の場合には遠心端の移植 骨吸収が著明 31 , 32) であったと報告している。また移 植骨が増大した症例17,31）も散見され，母床骨の状態 や残存骨膜などにより移植骨の消長が左右され, 予知 性の悪い移植骨といわざるを得ない。一方 VICにお いては骨の吸収について論じている報告はないが, 著 者らの結果ではほとんど移植骨の吸収や増大は長期に 亘り認められず, きわめて予知性の高い骨移植が可能 であると思われた。

\section{移植骨の生着について}

NVIC の生着率は, $83.3 \%$ から $96 \% 17,31,32,34,37$ 39) で, これらの移植骨が生着しなかった原因としては,
移植骨の感染 32,37$)$, 被覆粘膜の穿孔や哆開 39$)$, 移植骨 の動摇 ${ }^{35)}$, 死腔31)を挙げている.これらの原因を最小 限にするため, 移植骨の高さを $2 \mathrm{~cm}$ 以下35)にしたり，

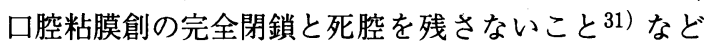
を挙げている。一方 VICによる下顎再建の生着率に ついては, David らは $32 / 35$ 例 $(91 \%)^{4)}$, Taylor ら は $9 / 10$ 例 $(90 \%)^{8)}$ であり著者らも34/38例 (90\%) とほほ同様の結果であった. 失敗の原因としては血管 柄への外傷と圧迫, 解剖学的原因 ${ }^{4)}$, 動脈の血栓 ${ }^{8)}$ な どが挙げられている. 著者らの除去例の原因としては, 単径皮弁の血行不良による被覆皮弁の壊死が原因となっ たもの，上甲状腺動脈からの動脈圧が不足し骨性癒合 が得られず骨が感染したもの, 静脈の血栓によるもの, 原因は不明であるが移植後 6 か月目に VIC 自体が感 染したものであった.

\section{プレートについて}

われわれはつぎの点で, 大型の再建用プレートがミ ニプレートよりも VIC 固定には適していると考えて いる. すなわち，1. 術後の䕱間固定期間が少なく，術 後回復が早い, 2.プレートが強固であるため, 口腔 を機能させながら治瘉させることが可能で, 術後早期 に義歯の装用ができる，3．プレートに合わせて下顎 の形態を再現できる，などである．しかし AO の再建 用のネジは本来 bicortical にネジ止めを行うもので ある40) が, 腸骨の内側には深腸骨廻旋動静脈があり, この血管柄の損傷を避けるため monocortical にネジ 止め固定を行わざるを得なかった.このため本来有し ていた強固なネジ止め固定ができにくく，ネジの緩み などが生じ易くなっていた。しかし実際の症例では, monocortical でもネジの緩みのためにプレート除去 を早期に行う必要があった症例はなかった。 そこで従 来の $\mathrm{AO} よ り も さ ら に$ 強固なネジ止め固定が得られ る方法として開発された THORP 41 ，42）を使用した. この THORP のプレートは従来の再建用 $\mathrm{AO}$ プレー トに比較しさらに厚く, 幅が大きくなっており, プレー トの屈曲時の操作性の悪さや, プレートを被覆してい る顔面皮膚の菲薄化が見られたが, VIC の固定には従 来のプレート固定システムに比較し, 優れた固定が得 られる方法と思われた。

\section{インプラントについて}

欠損の大型化に伴い義歯の大型化は避けられず, こ れに起因する義歯装着時の不快感, 義歯の維持安定の 喪失, 咀嚼能率の低下, 鈎歯への咬合圧の過利負担に よる鈎歯の早期表失などの問題が生じている。これら を改善する目的にて，インプラントの応用を試みた.

しかし移植骨に植立したインプラントに関する長期 観察例の報告は皆無であるが, NVICに Brånemark がインプラントを植立 ${ }^{43)} し$, 顎補綴領域への応用が行 われて以来さまざまな臨床報告がなされており，血管 柄を付けない移植骨にインプラントを植立するにあたつ 
ての基礎研究もAlberksson の一連の研究44,45）を初 めとして多数見られる。またVIC にインプラントを 植立した臨床報告が Lukash ら 46）を初めとしてなさ れているが，これらの基礎的研究はあまりなく47,48), 試行錯誤的に行われているのが現実である。そこでわ れわれは血管柄付腸骨にインプラントを行う場合つぎ のような原則に基づいて行っている.すなわち，1. バイコルチカール・サポートとし, 主に腸骨稜に支持 をもとめる, 2 . インプラント上部構造の高さとフィ クスチャーの長さを比較し, インプラント上部構造の 高さのほうが高くなるようであれば, オーバーデンチャー 型のインプラント義歯とする，3.フィクスチャーの 本数がインプラント支持価より少ない場合は, オーバー デンチャー型のインプラント義歯とする，4. 被覆上 皮は薄く非可動性とする，5. 移植骨生着後にフィク スチャーの植立を行う，などである。このようにイン プラントを植立すると初期の生着は良好であることか ら,インプラントの移植床としての VIC は有用であ る可能性が示唆された.

インプラント補綴後と義歯装用時で口腔機能を比較 検討した報告はなく，他の報告と比較することは不可 能であるが, 著者らの結果では咀嚼能力を比較してみ ると総じてインプラント補綴後の方が上昇し, 捸取可 能な食物の大きさも大きくなる傾向にあった。これは インプラントによる確実な維持源ができたためと思わ れた. しかし舌全摘出を併用した症例では舌の動きが ほとんどないため, 咀嚼能力としての上昇は認めなかっ たが，摂食可能な食品の大きさを小さくしなくとも捸 取可能になっていた。これも強固な義歯の維持安定が 得られたためと思われる.またほとんどの症例で義歯 に比較し補経物が小型化し, 装用感が改善され, 不快 感が軽減したと述べていた。これらの改良された機能 がある半面, 会話明瞭度ではほとんどの症例で著明な 改善傾向を示さず, 逆にインプラント義歯装着直後に 構音時に息の漏れを訴える患者も見られた。しかし総 合的に考えて, インプラント義歯の顎補綴への応用は, 口腔機能回復の上からも有用であると思われる.

\section{結語}

VIC による下顎骨の再建例 38 症例について検討し 以下の結果を得た。

1. 一次再建, 放射線性骨髄炎, 延長骨移植症例な どの母床骨の状態が良好とは言えない状況においても $34 / 38$ 例 $(90 \%)$ の良好な生着が得られた。

2.VIC の除去理由は移植の血行障害による移植骨 の感染 2 例, 移植骨の被覆皮弁の壊死 1 例, 移植後 6 か月目の VIC の感染 1 例であった.

3. VIC 採取側の合併症は歩行障害, 大腿部知覚異 常, 単径部の感染が認められたが, これらの症状は術
後 1 年以内にほとんど消失していた. 長期にわたる重 篤な合併症状は無く，比較的安全な血管柄付骨移植方 法と思われた。

4. 移植後比較的早期に義歯の装用が可能であった.

5. 移植後の骨量の変化はほとんど見られなかった。

6. VIC に対するインプラント植立の初期の生着率 は良好で，インプラントの移植床としての有用性が示 唆された.

7. 義歯とインプラント義歯装用時で口腔機能を比 較してみると, 会話明瞭度試験では余り改善傾向を示 さなかったが, 咀嚼能力は改善傾向を示し, インプラ ント義歯の顎補綴領域の有用性が示された.

本論文の要旨は, 第18回日本頭頸部腫瘍学会 (1994年 7 月, 札幌), 第19回日本頭頸部腫瘍学会 (1995年 6 月, 大阪), 4 th International Congress on Oral Cancer (September 1995, Ogaki), 第20回日本頭頸部腫瘍学会 (1996 年 6 月, 福井)にて発表した。

\section{引用文 献}

1）佐藤淳一, 瀬戸晥一：下顎再建の実際. 頭頸部 腫瘍 19: 17-21 1993.

2) 佐藤淳一, 安元信也, 他 : 遊離組織移植による 口腔顎顔面領域の機能再建に関する臨床的研究 第 1 報, 神経付前腕皮弁の神経に血管柄を付け た場合と付けない場合の口腔知覚機能再生に関 する比較検討. 日口外誌 41: 690-698 1995.

3）北村秀哉：下顎骨再建における血管柄付骨移植 としての肩甲骨, 腸骨, 腓骨, 肋骨の形態計測 による比較検討. 日口外誌 41: 928-944 1995.

4) David, J.D., Euqeue, T., et al: Mandibular Recondtruction with vascularized iliac crest; A 10-year experience. Plast Reconstr Surg 82: 792-801 1988.

5) Riediger, D.,: Restration of Masticatory function by microsurgically revascularized iliac crest bone grafts using endosseous implants. Plst Reconstr Surg 81: 861-876 1988.

6) 山本為之：総義歯臼歯部人工歯の配列について （その 2 ）一特に反対咬合について一. 補綴臨床 $5: 392-4001972$.

7) 田口恒夫: 言語障害治療. 医学書院, 東京, 1966.

8) Taylor, G.I., Townsend, P., et al: Superiority of the deep circum flex iliac vessels as the supply for free groin flap. Clinical work. Plast Reconstr Surg 64: 745-759 1979.

9) Taylor, G.I.: Reconstruction of the mandibule with free comopsite iliac bone graft. Ann Plast Surg 9 : 361-376 1982.

10) Mckee, D.M.,: Microvascular bone trans- 
plantation. Clinics Plast Surg 5: 283-292 1978.

11) Ariyan, S. and Finseth, F.J.: The anterior chest approach for obtaining free osteocutaneus rib graft. Plastic Reconstr Surg 62: 676-685 1978.

12) Serafim, D., Villarreal-Rios, A., et al: A rib containig free flap to reconstruct mandibular defects. British J Plast Surg 30: 263-266 1977.

13) William, M.S., Joseph, C.B., et al.: The Osteocutaneous scapular flap for mandibular and maxillary reconstruction. Plast Reconstr Surg 77: 530-545 1986.

14) David, A.H.,: Fibula free flap: A new method of mandible reconstruction. Plast Reconstr Surg 84: 71-79 1989.

15) Benard, M.O., Graham, J.G., et al: Folded free vascularized fibula transfer. Plast Reconstr Surg 82: 311-319 1988.

16) Souter, D.S., Frcs (Ed) M.C., et al: Immediate reconstruction of the mandible using a vascuarized segment of radius. Head and Neck Surg Mar/Apr: 232-246 1986.

17）松本秀治：下顎骨骨移植の臨床的ならびに実験 的研究. 軍馬団雑誌 348: 561-585 1942.

18) Ivy, R. and Epes, B.H.: Bone grafting for defects of the mandible. Minit Surg 60: 2862931927.

19) Synder, C.C., Bateman, J.M., et al: Mandibular-facial restoration with live osteocutaeous flap. Plast Reconstr Surg 45: 14191970.

20) Siemssen, S.O., Kirkby, B., et al: Immediate reconstruction of a resected segment of a lower jaw using a compound flap of clavicle and sternomastoid muscle. Plast Reconstr Surg 61: 724-735 1978.

21) Ketchum, L.D., Master, F.M., et al: Mandibular reconstruction using a composite island rib flap Plast Reconstr Surg 53: 471-476 1974 .

22) Cuona, C.B. and Ariyan, S.,: Immediate reconstruction of a composite mandibular defect with a regional osteomusculocutaneous flap. Plast Reconstr Surg 65: 4174831980.

23) Maruyama, Y., Urita, Y., et al.: Riblatissimus dorsi osteomyocutaneous flap in reconstruction of a mandibular defect. Br J Plast Surg 38: 234-237 1985.

24) Green, M.F., Gibson, J.R., et al.: A onestage correction of mandibular defects using a split sternum pectoralis major osteo-musculocutaneous transfer. $\mathrm{Br} J$
Plast Surg 34: 11-16 1981.

25) Weaver, A.W., Smith, D.B., et al.: Frozen augoenous mandibular stent graft for immediate reconstruction in oral cancer surgery. Am J Surg 126: 505-506 1976.

26) Harding, R.L.: Replantation of the mandible in cancer surgery. Plast Reconstr Surg 19: 373-383 1957.

27) Schwartz, H.C.,: Mandibular reconstruction using the dacron-urethe prosthesis and autogenic cancellous bone: review of 32 cases. Plast Reconstr Surg 73: 387-392 1984.

28）大西正俊, 山崎安晴, 他 : 人工骨としての多孔 質アパタイト一臨床応用を中心として一. 歯科 ジャーナル 17: 623-633 1983.

29) Wolford, L.M., Wardrop, R.W., et al: Coralline porous hydroxylapatite as a bone graft substitute in orthognatic surgery J Oral Maxillofac Surg 45: 1034-1042 1987.

30) Kent, J.N., Zide, M.F., et al: Hydroxylapatite block and particles as bone graft substitutes in orthognathic and reconstructive surgery. J Oral Maxillofac Surg 44: 597-605 1986.

31）松浦正朗, 瀬戸晥一, 他：自家遊離腸骨移植に よる下顎再建とその術後経過について.日口外 誌 34: 1366-1381 1988.

32）工藤啓吾, 藤岡幸雄 : 下顎骨骨移植の臨床的研 究 その 1,28 例の予後について. 日口外誌 21: 180-187 1975.

33) Lindstrom, J., Branemark, P., et al: Mandibular Reconstruction using the performed autologous bone graft Scand J Plast Reconstr Surg 15: 29-38 1981.

34）吉賀浩二, 高田和彰 : 下顎の再建. 頭頸部腫瘍 19: 12-16 1993.

35) Boyue, P.I.,: Restoration of osseous defects in maxillofacial causalities $\mathrm{J}$ Am Dent Assoc 78: 767-776 1969.

36) Burchardt, H. and Enneking, W.F.: Transplantation of bone. Symposium on organ transplatation. Surg Clin North Am 58: 403-427 1978.

37) Macomber, W.B., Shepard, R.A., et al.: Mandibular bone graft. Plast Surg $3: 570$ 5851948.

38) Blocker, T.G., Roy, A. et al: Mandibular reconstruction, world war II . J Oral Surg $8:$ : 153-157 1950 .

39) Obwegeser, H.L: Simultaneous resection and reconstruction of parts of the mandible via the intraoral route in patients with and without gross infection. Oral Surg 
Oral Med \& Oral path 21: 693-705 1966.

40) Chow, J.M., Hill, J.H., et al: Primary mandibular reconstruction using the A-O reconstruction plate. Laryngoscope 96: 768-773 1980.

41) Raveh, J., Stich, H., et al: Konservative und chirurgishe massnahmen zur wiederherstellung der kiefergelenk funcktionen und methoden zur defektueberbrueckung am unterkiefer. Schweiz Mschr Zahnheilk 90: 920-932 1981.

42) Raveh, J. Sutter, F. et al: Ligid fixation of the claniomaxillofacial skeluton. Buffsworth Hierenwan 1992 Swissland.

43) Branemrk, P.I., Lindstron, J., et al: Reconstruction of the deffective mandible. Scand J Plast Reconstr Surg 9: 116-128 1975.

44) Albrektsson, T. and Albrektsson, B.: Microcirculation in grafted bone. A chamber technique for vital microscopy of rabbit bone transplants. Acta Orthop
Scand 49: 1 - 71978.

45) Albrektsson, T. and Sennerby, L.: Direct bone anchorage of oral implants clinical and experimental considerations of the concept of osseointegration. Int. J. Prosthodont 3:30-41 1990 .

46) Lukash, F.N., Sachs, S.A., et al: Osteointegrated denture in a vascularized bone transfer: functional jaw reconstruction. Annals of Plastic Surgery 19: 538-544 1987.

47) Shirata, T., Schmelzeisen, R., et al.: Immediated insertion of two types of implants into vascularized bone grafts used for mandibular reconstruction in miniature pigs. Oral Surgery Oral Medicine Oral Pathology 77: 222-231 1994.

48) Dattio, D.J., Misch, C.M., et al.: Interface analysis of hydoxyapatitecoated implants in human vascularized iliac bone graft. Int J Oral Maxillofac Implants 10: 405-409 1995. 